\title{
INTEGRATION OF PRIVATE SOCIAL NETWORK IN PLM SYSTEMS
}

\author{
Alen Zubić, Nenad Bojčetić, Dragan Žeželj
}

Preliminary notes

Today's PLM systems are limited by not providing platform for discussions among workers and other related human entities in product development. Sociotechnical model suggests that the communication is essential when trying to implement system traceability and when there is a need for better understanding of product development process. This paper proposes integration of private social network in PLM system to improve management of communication in product development process, in order to capture design knowledge.

Keywords: automotive industry; data management; PLM; PDM; system complexity; social network; sociotechnical system; traceability

\section{Integracija privatnih društvenih mreža u PLM sustave}

Prethodno priopćenje

Današnji PLM sustavi pružaju ograničenu podršku komunikaciji između konstruktora i drugih srodnih ljudskih subjekata u razvoju proizvoda. Sociotehnički model sugerira da je komunikacija bitan čimbenik pri uspostavljanju sustava sljedivosti te u slučajevima kada postoji potreba za boljim razumijevanjem procesa razvoja proizvoda. U radu se predlaže uključivanje privatne društvene mreže u PLM sustav u cilju poboljšanja upravljanja komunikacijom tijekom procesa razvoja proizvoda u cilju dohvaćanja konstrukcijskog znanja.

Ključne riječi: automobilska industrija; društvene mreže; kompleksni sustavi; PLM; PDM; sociotehnički sustavi; sljedivost; upravljanje podacima

\section{Introduction}

With today's increased level of product complexity [1] during the product development, traceability is an approach which naturally fits into an environment where decisions need to be made fast and precise with the broad spectrum of context surrounding the product. Knowing the decision making process and how conflicts inside issues were resolved helps with future versioning and product variants. Knowledge gathered during the development process can be reused and it helps to achieve better efficiency while shortening the time for finalizing similar future projects [2]. New members of the team are able to learn about the history and the timeline of development of the product and it can help them to easily integrate into the team. This is why it is important to have good product traceability.

While developing mechatronic systems, every module of the system with a specific function should be applicable to different context of another system. This allows future development to take existing project and use it in another as a module that does its function regardless of a new context [3]. Unfortunately, there are often new requirements that change existing modules and the change can affect other parts of the system. By enabling engineers to communicate inside PLM (Product Lifecycle Management) system, additional knowledge about previous product is built and therefore easier to recover later when needed.

Complexity of product development inside company should be high enough to suggest implementation of system traceability [4]. In case there is low complexity inside an organization, advanced traceability methods are not necessary to boost long term productivity. Sociotechnical meta-model is an approach which can be used to model product development process much more in-depth, therefore supporting traceability. It uses social part of the meta-model together with technical and since communication is part of the social aspect, it is worth capturing for creating knowledge database (Fig. 1). Fig. 1 is the graphical representation of the research summary to be seen in this paper.

The lack of social interaction within PLM systems could be addressed by implementing private social network. Its goal would be to capture as much communication as possible to support traceability based on sociotechnical model. Sociotechnical model proposes communication as essential part of product development process and therefore communication is prone to be documented and analysed. Question is, can PLM system and private social network platform be merged?

\section{Product development complexity}

Recently, automotive industry faced few important challenges. Some of these challenges are significant $\mathrm{CO} 2$ restrictions, market drifts and economic crisis, which demanded sudden changes in project management. Economically, budgets for individual projects were reduced and on the other hand system complexity rose due to the demand for fuel efficient vehicles. Fuel efficiency is trying to be achieved by looking into green energy sources and building hybrid vehicles. Hybrid vehicles made system complexity harder to handle because multidisciplinary approaches had to be introduced to achieve seamless combination of multiple power trains in one vehicle. Old well established and well known methods had to be modified. Now, different fields of science are coming together and therefore new data model had to be developed to manage this complexity of all newly introduced artefacts in intensified cooperation, joint venture and network structure in manufacturing [5].

\section{Traceability}

System traceability is the power of knowing how all artefacts, created during the product development, are related to each other. Traceability should be able to 
provide answers to 'why?', 'how?' and 'when?' specific events occurred, 'who?' is responsible, 'what?' was affected by those events and 'where?' it happened.

When talking about supporting traceability, there are some pitfalls that have to be considered. If traceability is not well implemented or the information entering traceability support system is not correct, it can impact project cost and schedule. Decrease in system quality, increase in the number of changes and iterations in design, loss of knowledge due to misunderstanding and misleading information are some of the common problems that can occur [6]. During product design process, information is recorded and evaluated. Information occurs in variety of forms such as sketches, drawings, notes, meeting recordings, CAD models, production drawings, calculations, reports and other [6]. Storga therefore argues that the effective traceability is highly dependent on the effective utilization of existing engineering information and records.

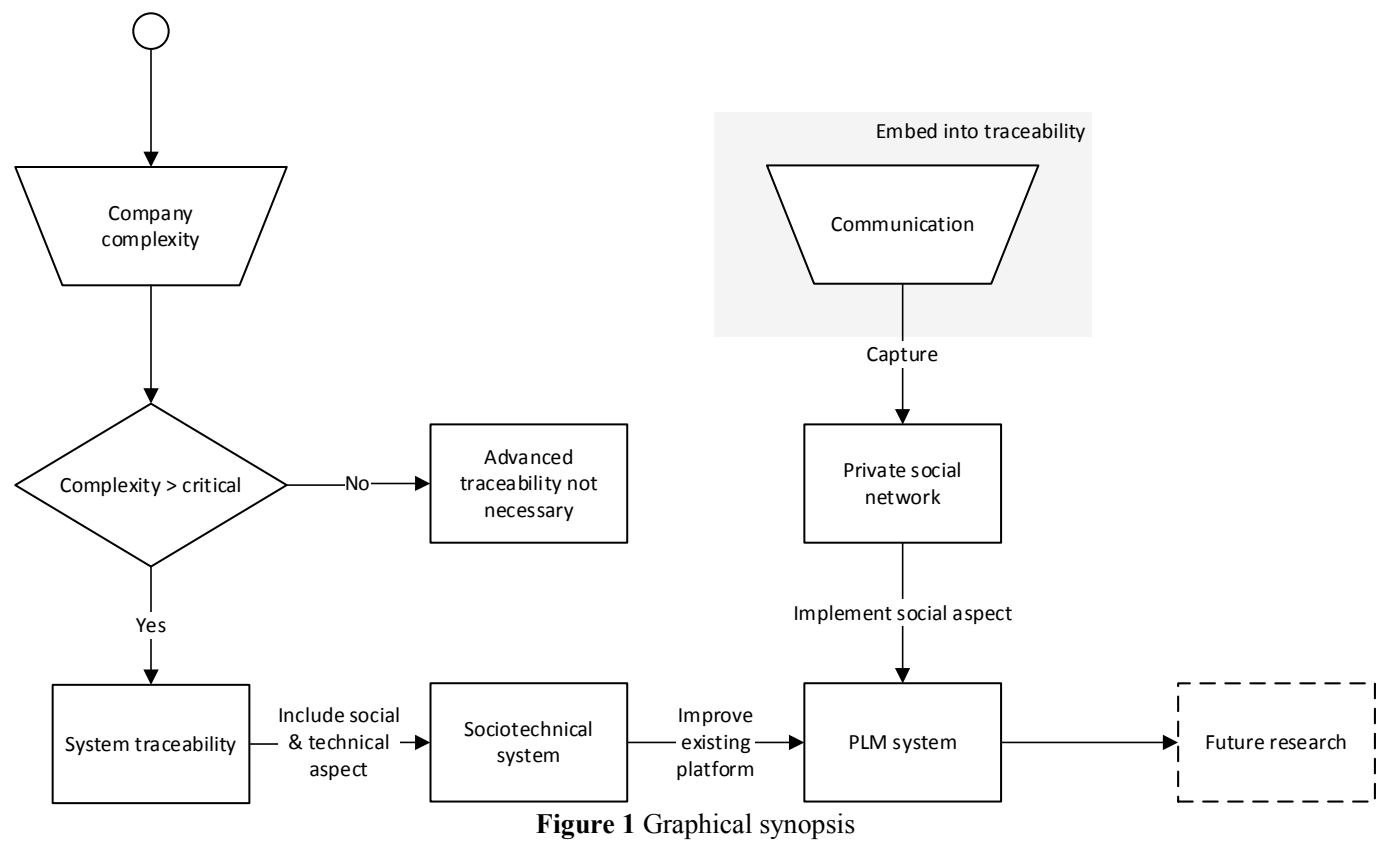

In order to fully understand an instance of information, it is important to know the circumstances in which it has been developed and recorded. Traceability then allows engineers to better understand and make better judgments about their decisions based on the previously collected and now well known facts. This is why it is important to leverage all relevant information no matter where it originated, no matter of its form and no matter where it resides [6] in order to help the company provide better services, produce better products and therefore ensure healthy growth.

Relations that exist within product development lifecycle help anyone who may be concerned to better understand the rationale behind previously made decisions [6]. In order to build quality network of relations, different research groups approach traceability issues from different perspectives. They state that it is important to address knowledge integration [7], communication, handling complex dependencies between requirements and components [8], ontological retrieval of unstructured documents [9] and other areas for effective traceability to be ensured. Storga suggests four main areas to focus on in order to understand what is necessary to have complete traceability support. Those are requirements, changes, characteristics and decision traceability issues. To support traceability in social aspect of sociotechnical model and to ensure there is a possibility to show the relations that are important for describing system architecture, private social network platform captures some portions of communication and then post-processing methods will allow further dive into system architecture analysis and therefore provide more insight about the product structure itself.

\subsection{Sociotechnical system}

One of the proposed methods for in-depth product development process modelling is sociotechnical metamodel (Fig. 2). Better overview and understanding of system complexity is provided by detailed process and sub-process model within product development environment. It defines basic system functions as interaction between human and machine and as communication between humans. Product development process can then be modelled based on those two functions. With this approach it is possible to model the system on lower level in contrast to what was possible before, therefore it gives better overview of the system.

Methods and tools like CAx and PLM technologies had to be embraced and put into the everyday process of product development. In the end, all of this should come together in a model describing how to deal with the process related to product development under consideration of social behaviour, design methodologies and IT services [5]. 


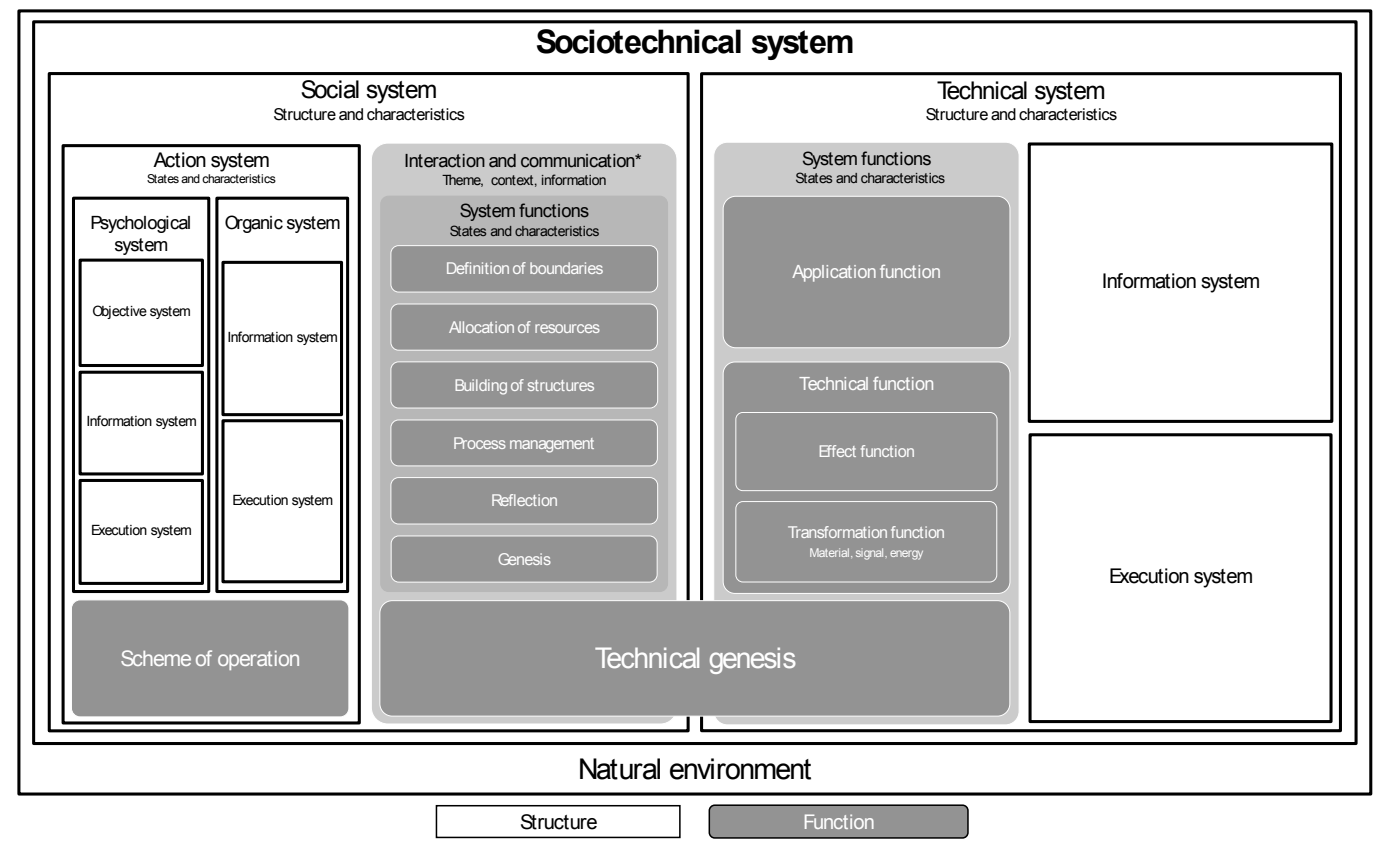

Figure 2 High level meta-model structure of sociotechnical system [5]

As humans interact with machines (for example computers), which often provide us with tools for solving different scenarios, it is important that those tools are efficient and produce quality results [5]. If produced results were not correct, it would not be possible to support traceability. Efficiency should be always taken into account as efficiency of the whole project depending on the efficiency of partial steps in the project development.

Implementation of private social network in PLM system supports social side of sociotechnical meta-model by providing platform for capturing communication.

Table 1 Evaluation of private social network platforms

\begin{tabular}{|c|c|c|c|}
\hline & $y=$ & Q & ๑ SOCIALCAST \\
\hline LAN (not remote) implementation & $x$ & $x$ & $\checkmark$ \\
\hline Mobile access & $\checkmark$ & $x$ & $\checkmark$ \\
\hline Ease of implementation & $x$ & $\checkmark$ & $\bullet$ \\
\hline Connect to existing user database & $\checkmark$ & $x$ & $\checkmark$ \\
\hline Search & $\checkmark$ & $\bullet$ & $\checkmark$ \\
\hline Archive & $x$ & $x$ & $\checkmark$ \\
\hline Private messages & $\checkmark$ & $x$ & $\checkmark$ \\
\hline User groups & $\boldsymbol{V}$ & $x$ & $\boldsymbol{\nu}$ \\
\hline Price & $\bullet$ & $\checkmark$ & $\bullet$ \\
\hline$\Sigma$ & 2 & -4 & 7 \\
\hline
\end{tabular}

\section{PLM systems as communication capturing platform}

Research of communication tools inside PLM systems used by R\&D departments and other teams that are part of product lifecycle led to the conclusion that there is a noticeable space for implementing platform in form of private social network. Advanced communication methods, which are part of private social networks, can be used as a tool for easier and faster decision-making processes. Information captured during software usage can be stored in the database whose records can later be used as a knowledge base. When implementing this type of communication platform, it is expected to shorten the product development time and to get more efficient intellectual property management.

The acquisition of dependency structures among system artefacts represents a special challenge. Often, system structures only exist as implicit knowledge and are shared among several specialists, particularly in early phases in product design. Non-quantified information has to be modelled. Future methods for analysing captured communication during product development process can be used to help model those relations.

Complex systems require a methodical acquisition that encourages users not to forget or neglect relevant information content. Private social network inside PLM 
system is platform that enables acquisition at least part of this valuable information content.

\subsection{Private social network}

There are a number of PLM systems and private social networks available on the market. Some of the PLM systems are PTC Windchill, ENOVIA SmarTeam and SIEMENS NX Teamcenter together with private social network platforms such as Yammer, Disqus and Socialcast. All of them were evaluated in regard to number of factors involving ease of implementation, mobile access, search capability, price, etc. (Table 1).

Socialcast fairly satisfies important terms where Disqus and Yammer fall behind in regard to those requirements. Opportunity for local implementation is the most important requirement. Companies want to have their data under control and do not want to store it in the cloud or out of their jurisdiction. Yammer is Software as a Service (SaaS) and is not available for local installation, the same as Disqus. Data security is a priority and therefore Disqus and Yammer should be eliminated even by the first requirement.

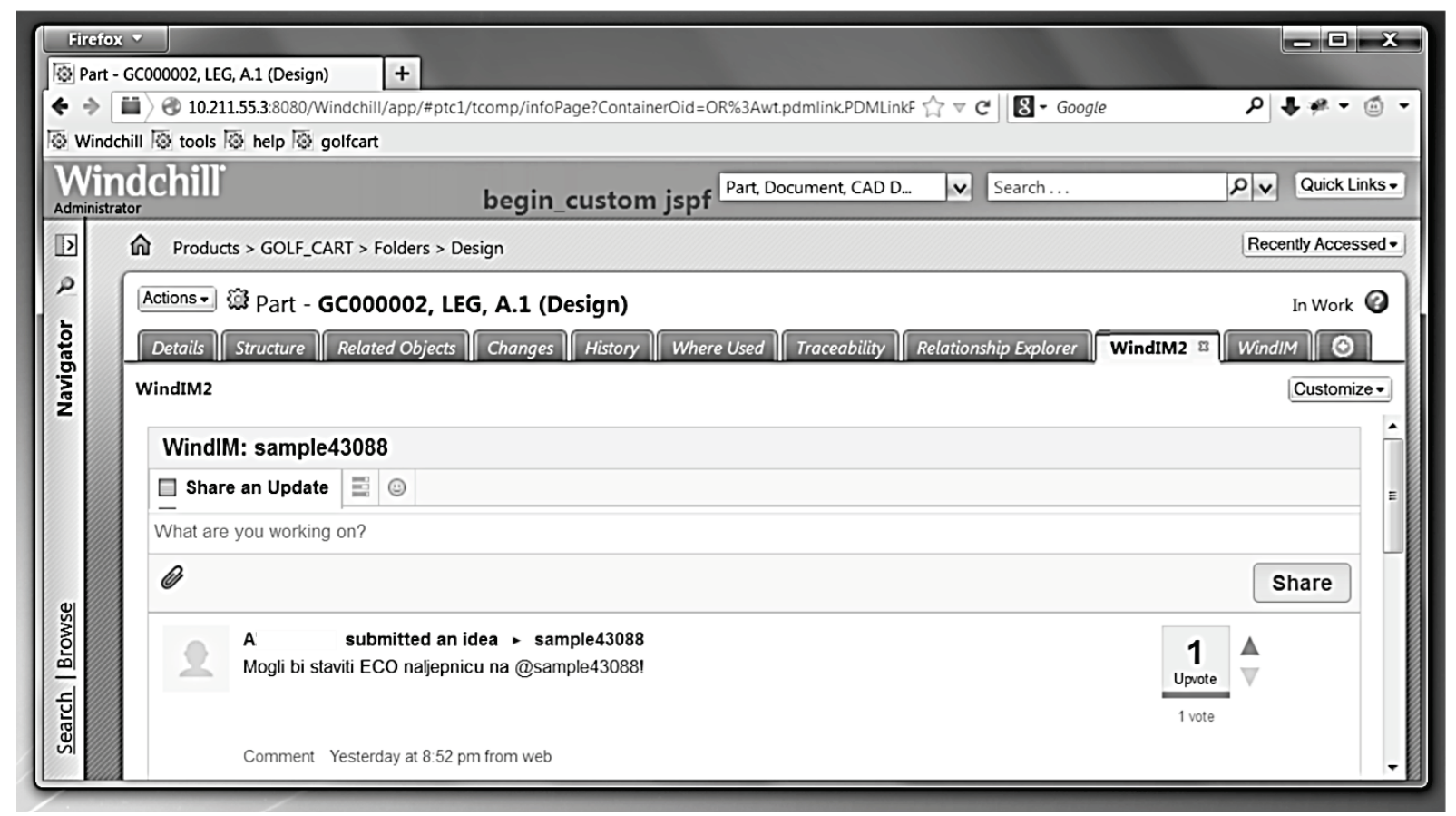

Figure 3 Socialcast implementation inside PTC Windchill PLM system

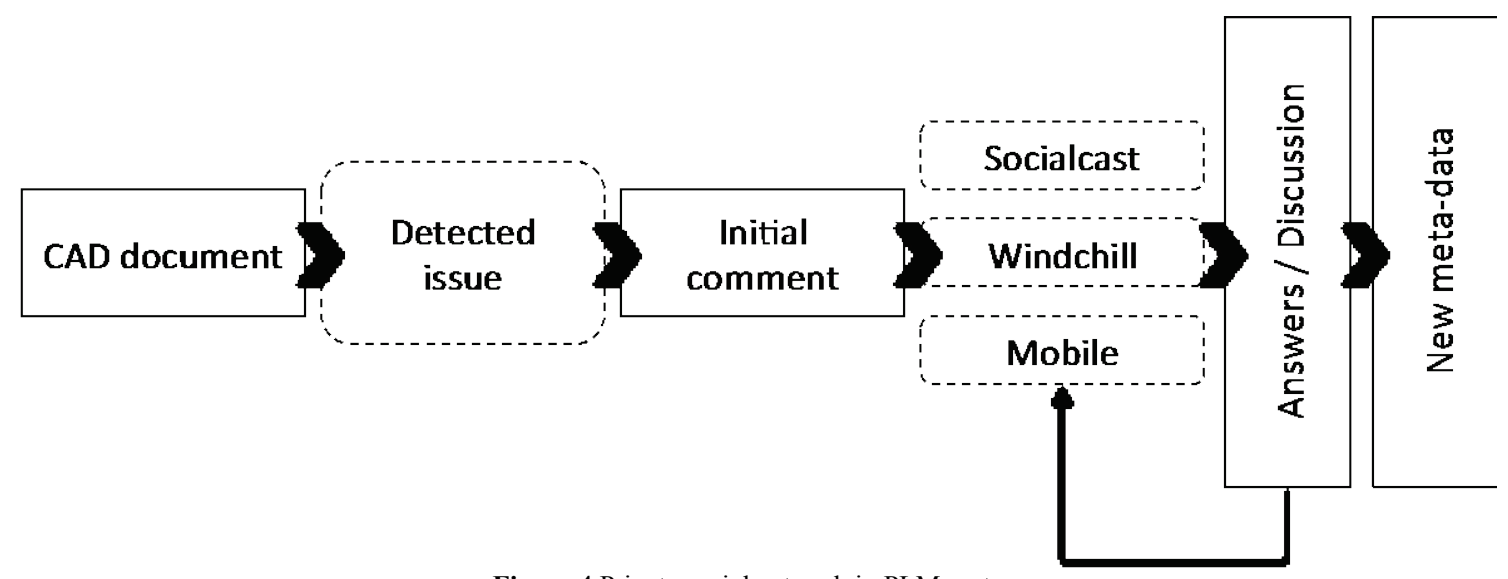

Figure 4 Private social network in PLM system

Regarding compatibility, SmarTeam and Teamcenter tend to keep their software within boundaries that do not allow heavy interventions in the system core operation and therefore are not suitable for Socialcast integration. On the other hand, PTC Windchill is written in Java, completely customizable and well documented. Customization offers opportunity to implement Socialcast as a module, which is integrated as a part of the system.

Based on previous evaluation PTC Windchill together with Socialcast were the platforms chosen to be merged together (Fig. 3). PLM systems store and keep organized large variety of documents, parts, assemblies and other type of data. Implemented private social network enables users to discuss the content of all those documents, suggest different solutions, comment on other people's thoughts, etc. (Fig. 4) All this at precise locations inside PLM system with precisely selected group of people. Discussions are automatically structured and people that are part of the discussion are automatically notified when new information arrives. More users get engaged and 
respond faster to current issues. Socialcast also provides mobile phone application which additionally helps to achieve better user engagement.

\section{Proof of Concept}

Socialcast interface was seamlessly integrated into the Windchill interface (using Java beans and javascriptcalls). This is done in Windchill because Windchill (PLM/PDM) is considered as the main product information integration application that designer uses during his/her work on the product. Using the single LDAP server for the Windchill and for the Socialcast to solved security and access rights was proved to be right solution. With this solution user rights and profiles created in the Windchill environment can be used in the Socialcast as well. Some customizations were necessary because the Windchill was chosen as the primary system and Socialcast's user accounts and user rights schema had to be customized to accommodate Windchill schema (profiles, groups, users rights, etc).

Proposed solution can be useful in any phase of the product development process, but the authors considered design phase in the proof of concept so the basic functionalities could be tested. The design phase is used because in this phase designers spent most of their work hours and the need for communication and information exchange is most intense.

Testing was done in two phases in a controlled environment. In the first phase the authors were playing different roles (novice designer, experience designer and head of department) to login to Windchill and to interact with the Socialcast.

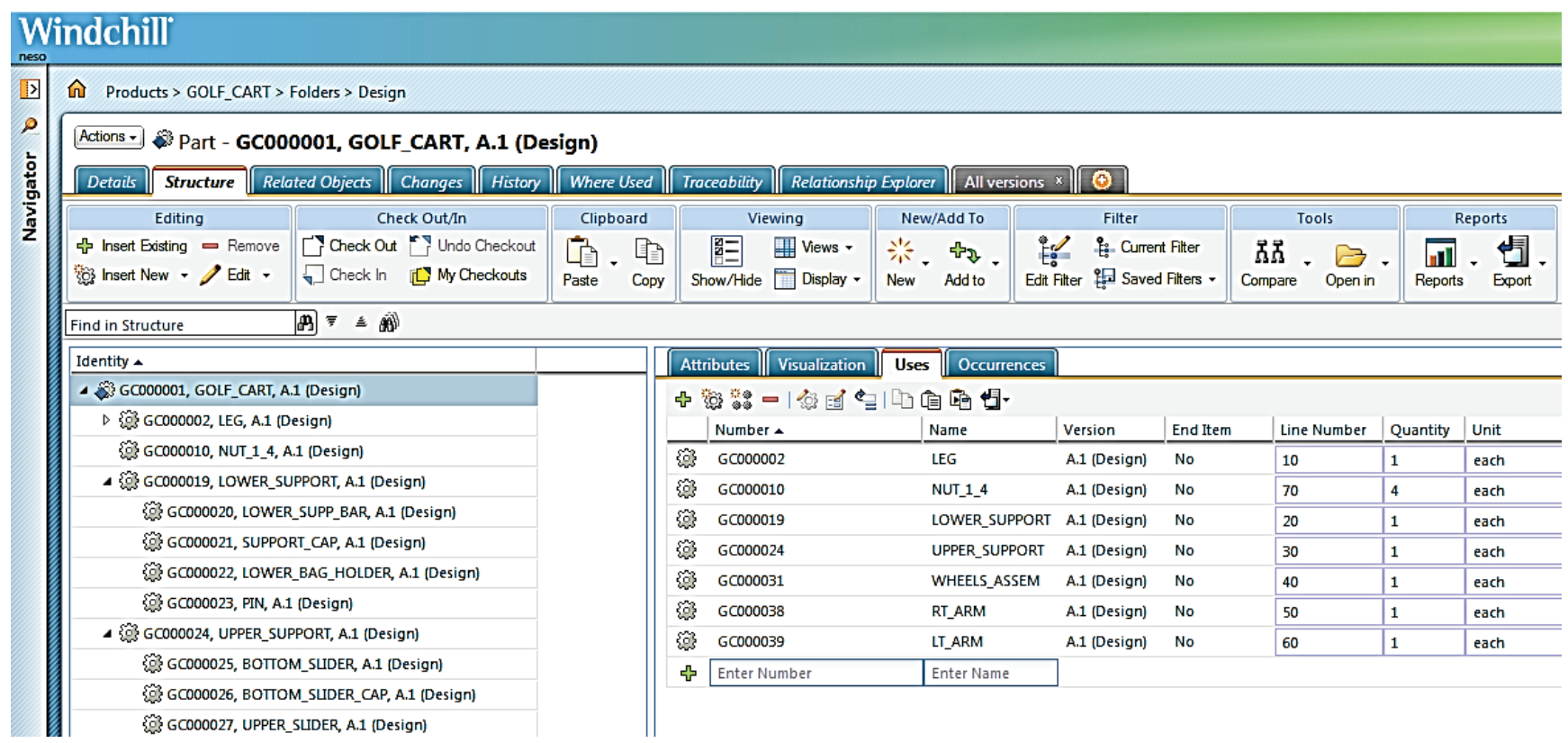

Figure 5 Test product structure

Each of selected roles has different rights (accessing different information about the product and the system in general). The design of the Golf cart [Fig 5.] was used as the product for testing. Testing scenario was as follows:

- experience designer discusses new customer requirement for design change with head of department as this is a new requirement that a customer wants on the product,

- after discussion experience designer interacts with novice designer and instructs him how to address customer's new requirement,

- after the novice designer completes his assignment, experience designer and head of department discuss novice designer performance,

- head of department makes a suggestion that a novice designer should be promoted, on the ground of his work performance (this part of the discussion is private between experience designer and head of the department and it is not available for other users to see).

During the second phase of testing, a group of students was used as users of the system. The students were assigned with imaginary problems concerning different parts of Golf cart assembly.

Students have asked help through Socialcast and received comments and solutions in the form of sketches, text explanations, links and questionnaires.

This part of the testing revealed a major problem of system usage. The problem is how to keep the focus of the discussions about the product to the problem at hand. The authors think that the proposed solution requires quality education about the system usage and above all a user's discipline.

The testing has shown that communication captured during designer's interaction using proposed solution can be stored and later used as the best practice. One issue that was recognized and planned for the next research phase was how to deal with product promotion cycle and what to do with discussions related to particular revision or version when it is promoted (current suggestion, that has to be tested, is to render discussions, relating to a particular version or revision, read only). 


\section{Conclusion}

Current solutions in PLM systems regarding social interaction are limited. Our everyday lives, at the other hand, are filled with tools for social interaction and many people use a number of them daily. Product development teams are part of the sociotechnical systems where communication is essential for knowledge transfer. By supporting teams with private social network inside PLM system, communication through this platform becomes knowledge that is otherwise kept outside knowledge database.

Proof of Concept (PoC), which consists of Socialcast inside PTC Windchill, is the first step towards implementing the idea of embedded private social network in PLM system. Socialcast enables access to discussions even through mobile devices, therefore engaging users to participate in sharing their knowledge with less effort than before. Interactive communication methods are taken from today's popular social platforms and include Q\&A, voting to evaluate ideas, creating groups, sharing multimedia, etc. Private social network is expected to motivate users to share their knowledge without any burden because it is a more natural way of interacting with others. E-mail, paper and other similar communication methods are not well structured and are sometimes hard to trace. Private social network automatically structures information since the discussions are happening at specific place in complex system where the topic is initiated.

Developed PoC was successfully tested within a small group of students but case study in industry is necessary to prove the developed system efficiency.

\section{Acknowledgements}

This paper was done with support from Daimler AG.

\section{References}

[1] Königs, S. F.; Beier, G.; Figge, A.; Stark, R. Traceability in Systems Engineering - Review of industrial practices, stateof-the-art technologies and new research solutions. // Advanced Engineering Informatics. 26, 4(2012), pp. 924 940. DOI: 10.1016/j.aei.2012.08.002

[2] Bracewell, R.; Marina, G.; Moss, M.; Knott, D.; Wallace, K.; Clarkson, J. DRED 2.0: A method and tool for capture and communication of design knowledge deliberated in the creation of technical products, ICED, 2009.

[3] Sanchez, R.; Mahoney, J. T. Modularity, flexibility, and knowledge management in product and organization design. // Strategic Management Journal. 17, (1996), pp. 63-76. DOl: 10.1002/smi.4250171107

[4] Koehler, N. Traceability in Integrated Product Development, IcoRD, 2015.

[5] Naumann, T.; Königs, S.; Kallenborn, O.; Tuttass, I. Social Systems Engineering - An Approach for Efficient Systems Development. // Proceedings of the $18^{\text {th }}$ International Conference on Engineering Design, Copenhagen, 2011.

[6] Storga, M.; Bojcetic, N.; Pavkovic, N.; Stankovic, T. Traceability of Engineering information Development in PLM Framework, Eindhoven: Proceedings of the $8^{\text {th }}$ International Conference on PLM, 2011.

[7] Shannon, C.; Weaver, W. A mathematical theory of communication. // Bell Systems Technical Journal. 27,
(1948), pp. 379-423, 623-656. DOl: $10.1002 / j .1538-$ 7305.1948.tb01338.x

[8] N. Suh. The Principles of Design, Oxford University Press, 1990.

[9] Steward, D. The design structure system: a method for managing the design of complex systems. // IEEE Transactions on Engineering Management. 28, 3(1981), pp. 79-83. DOI: 10.1109/tem.1981.6448589

\section{Authors' addresses}

\section{Alen Zubić}

Sveučilište u Zagrebu

Fakultet strojarstva i brodogradnje

Ivana Lučića 5, 10000 Zagreb, Croatia

E-mail: alen.zubic@email.htnet.hr

izv. prof. dr. sc. Nenad Bojčetić

Sveučilište u Zagrebu

Fakultet strojarstva i brodogradnje

Ivana Lučića 5, 10000 Zagreb, Croatia

E-mail: nenad.bojcetic@fsb.hr

doc. dr. sc. Dragan Žeželj

Sveučilište u Zagrebu

Fakultet strojarstva i brodogradnje

Ivana Lučića 5, 10000 Zagreb, Croatia

E-mail: dragan.zezelj@fsb.hr 